\title{
Honoré de Balzac, Il Colonnello Chabert
}

\section{Marco Stupazzoni}

\section{(2) OpenEdition}

\section{Journals}

\section{Edizione digitale}

URL: https://journals.openedition.org/studifrancesi/4730

DOI: $10.4000 /$ studifrancesi.4730

ISSN: 2421-5856

\section{Editore}

Rosenberg \& Sellier

\section{Edizione cartacea}

Data di pubblicazione: 1 avril 2012

Paginazione: 164

ISSN: 0039-2944

\section{Notizia bibliografica digitale}

Marco Stupazzoni, «Honoré de Balzac, // Colonnello Chabert», Studi Francesi [Online], 166 (I | LVI) | 2012, online dal 30 novembre 2015, consultato il 19 novembre 2021. URL: http://journals.openedition.org/ studifrancesi/4730 ; DOI: https://doi.org/10.4000/studifrancesi.4730

\section{Questo documento è stato generato automaticamente il 19 novembre 2021.}

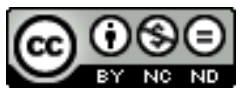

Studi Francesi è distribuita con Licenza Creative Commons Attribuzione - Non commerciale - Non opere derivate 4.0 Internazionale. 


\title{
Honoré de Balzac, Il Colonnello Chabert
}

\author{
Marco Stupazzoni
}

\section{NOTIZIA}

HONORÉ DE BALZAC, Il Colonnello Chabert, traduzione di Marco FRESCHI, Milano, Dalai editore, «Classici tascabili», 2011, pp. 103.

1 Segnaliamo questa nuova edizione italiana de Le Colonel Chabert di Balzac, curata nella traduzione da Marco Freschi che verosimilmente è anche l'autore della sommaria Introduzione che precede il testo.

2 Pubblicato nelle Études de Moeurs au XIXe siècle presso Mme Charles-Béchet nel maggio 1835 , con il titolo di La Comtesse à deux maris, Le Colonel Chabert sarà conosciuto con il suo attuale titolo ed inserito nella Comédie humaine nel 1844; anteriormente al 1835, l'opera era uscita con il titolo di: La Transation (marzo 1832) e de Le Comte Chabert (ottobre 1832) ne Le Salmigondis.

3 Nell'Introduzione citata, vengono esposti i momenti salienti della vita e della carriera letteraria dello scrittore, oltre ad alcuni cenni sulla genesi del romanzi, sulla sua sinossi e sulla sua fortuna, oltre che critico-letteraria («Il Colonnello Chabert, tra le opere di Balzac, ha sempre goduto di un posto di particolare favore, probabilmente perché $\mathrm{i}$ temi che affronta lo apparentano a una certa letteratura novecentesca», si legge a p. 15), anche teatrale e cinematografica. 